\title{
Studi Mitigasi Bencana Tsunami Dengan Menentukan Run- Up Dan Waktu Tiba Tsunami Daerah Banyuwangi
}

\section{Tsunami Disaster Mitigation Study by Determining Run-Up and the Banyuwangi Area Tsunami Arrival Time}

\author{
I Putu Agum Suriajaya Maha Putra ${ }^{1 *}$, Komang Ngurah Suarbawa ${ }^{1}$, I Gusti Agung Putra \\ Adnyana $^{1}$ \\ ${ }^{1}$ Program Studi Fisika, Fakultas Matematika dan Ilmu Pengetahuan Alam, Universitas Udayana, \\ Kampus Bukit, Jimbaran, Badung, Bali, Indonesia 80361 \\ Email: Agumsurya64@gmail.com*;kn_suarbawa@yahoo.co.id ; igaadnyana@unud.ac.id
}

\begin{abstract}
Abstrak - Telah dilakukan studi mitigasi bencana tsunami di Kabupaten Banyuwangi dengan melakukan penelitian mengenaianalisis run-up dan waktu tiba tsunami untuk daerah Banyuwangi. Penelitian dilakukan di Badan Meteorologi, Klimatologi dan Geofisika wilayah 3 Denpa sar dengan menggunakan softwere Tsunami Observation and Simulation Terminal (TOAST). Adapun data yang digunakan dalam penelitian ini adalah data sekunder berupa magnitude dan data kedalaman gempabumi bawah laut, dengan magnitude 7.0 sampai dengan magnitude 8.5 yang berpotensi menyebabkan tsunami dan data kedalaman gempa yaitu $18 \mathrm{~km}$ sampai dengan $65 \mathrm{~km}$. Dari hasil pengolahan data dengan aplikasi TOAST diperoleh hasil run-up dan waktu tiba tsunami. Data run-up maksimum yang diperoleh sebesar $9.718 \mathrm{~m}$ Sedangkan data waktu tiba tsunami tercepat sampai ke pesisir pantai yaitu 4 menit setelah terjadinya tsunami. Setelah mendapatkan data run-up maksimum dan waktu tiba tsunami tercepat, maka bisa dibuatkan skenario mitigasi bencana tsunami.
\end{abstract}

Kata kunci: Run-up stunami, waktu tiba tsunami, TOAST, mitigasi tsunami, gempabumi

\begin{abstract}
Tsunami disaster mitigation studies have been conducted in Banyuwangi Regency by conducting research on the analysis of run-ups and tsunami arrival times for the Banyuwangi area. The research was conducted at the Meteorology, Climatologyand Geophysics Agency region 3 Denpasar using the software Tsunami Observation and Simulation Terminal (TOAST). The data used in this study is secondary datain the form of magnitude and data on the depth of underwater earthquakes, with magnitudes of 7.0 to magnitude 8.5 that have the potential to ca use tsunamis and earthquake depth data of $18 \mathrm{~km}$ to $65 \mathrm{~km}$. From the results ofdata processing with the TOAST application obtained the results of run-up and tsunami arrival time. Maximum run-up data was obtained by 9,718 $\mathrm{m}$ while the fastest tsunami arrival time data to the coast is 4 minutes after the tsunami. Maximum run-up data is then used for mitigation and the fastest tsunami arrivaltime then can be made a mitigation scenario for tsunami disaster.
\end{abstract}

Key words: Tsunami run-up, tsunami arrival time, TOAST, tsunamimitigation, earthquake, earthquake depth

\section{Pendahuluan}

Bencana merupakan rangkaian peristiwa yang mengancam kehidupan manusia yang disebabkan oleh faktor alam maupun faktor manusia. Bencana alam adalah bencana yang diakibatkan oleh peristiwa atau serangkaian peristiwa yang disebabkan oleh alam, antara lain berupa gempabumi, tsunami, gunung meletus, kekeringan dan angin topan. Indonesia merupakan negara yang tidak terbebas dari bencana alam. Karenanya harus hati-hati, waspada dan selalu mempersiapkan diri dari bencana yang akan terjadi. Berdasarkan data seismic dunia, diketahui bahwa Indonesia memiliki tingkat kerawanan tsunami yang cukup tinggi, hal ini juga dapat diketahui dari banyaknya kejadian gempabumi yang mengakibatkan terjadinya gelombang tsnumai. Hal ini disebabkan posisi Indonesia yang ditinjau secara geografis berada pada pertemuan lempeng besar yang terus menerus bergerak. Lempeng tektonik besar tersebut yaitu lempeng Eurasia, lempeng tektonik Indo-Australia dan lempeng tektonik Pasifik.

Tsunami terjadi akibat adanya tumbukan antara dua lempeng yang menyebabkan terjadinya tegangan pada daerah terlemah, maka secara tidak langsung daerah terlemah akan melepaskan tegangang untuk 
kembali ke keadaan semula atau juga dengan gempabumi dalam skala besar yang terjadi ditengah laut. Gempabumi tersebut mengakibatkan terjadinya gerakan horizontal pada lempeng yang berupa patahan, dari patahan tersebut muncul gelombang dengan skala besar menuju pantai atau yang disebut dengan tsunami.

Data National Oceanic and Atmospheric Administration (NOAA) mengungkap pernah terjadi tsunami di wilayah Banyuwangi pada hari Jumat 3 Juni 1994, sekitar pukul 02.00 WIB. Banyuw angi merupakan salah satu wilayah Indonesia yang termasuk daerah raw an tsunami. Karena letak Banyuwangi berada pada zona subduksi yaitu di utara Banyuwangi yang merupakan pertemuan dua lempeng yaitu lempeng Indo-Australia yang bergerak dari utara ke selatan. Pertemuan lempeng ini menyebabkan terjadinya daerah subduksi yang menghasilkan terbentuknya palung laut. Berdasarkan uraian tersebut maka harus dilakukan tindakan yang preventif, diperlukan rancangan mitigasi bencana tsunami terutama di daerah Banyuwangi. Mitigasi sangatlah penting dan bermanfaat dalam meningkatkan kewaspadaan masyarakat terhadap bencana tsunami yang terjadi kedepannya.

Dalam penelitian digunakan aplikasi Tsunami Observation and Simulation Terminal (TOAST). TOAST adalah sebuah perangkat lunak untuk simulasi dan verifikasi tsunami dimana potensi bahaya dan penilaian terhadap tsunami yang terjadi diberikan dengan cepat. TOAST juga memiliki sebuah sistem di dalamnya yang dinamakan Easywave. Easywave menggunakan data pengukuran kedalaman gempabumi bawah laut sebagai model input untuk wilayah lautan agar dapat disimulasikan. Pada saat kejadian tsunami berlangsung, TOAST dapat dengan cepat memproses pemodelan tsunami secara real time dan langsung memberikan hasil. Oleh karena itu peneliti ingin mengambil topik penelitian tentang studi mitigasi bencana tsunami dengan menentukan run-up dan waktu tiba tsunami daerah Banyuwangi.

\section{Landasan Teori}

\subsection{Gempabumi}

Menurut teori tektonik lempeng, bagian luar bumi merupakan kulit yang tersusun oleh lempeng-lempeng tektonik yang saling bergerak. Apabila dua lempeng bertumbukan maka pada daerah batas antara dua lempeng akan terjadi tegangan. Apabila tegangan tersebut besar sehingga melampaui kekuatan kulit bumi, maka akan terjadi patahan pada kulit bumi di daerah terlemah. Kulit bumi yang patah tersebut akan melepaskan energi atau tegangan sebagian atau seluruhnya untuk kembali ke keadaan semula. Peristiwa pelepasan energi ini yang disebut gempabumi [1]. Batas lempeng tektonik dapat dibedakan berdasarkan bentuk utamanya yaitu konvergen, divergen, dan sesar mendatar [2]. Pada bentuk konvergen lempeng yang satu relatif bergerak menyusup di baw ah lempeng yang lain. Pada bentuk divergen kedua lempeng saling menjauh sehingga selalu terbentuk material baru dari dalam bumi yang menyebabkan munculnya pegunungan di dasar laut yang disebut punggung tengah samudera. Sedangkan pada tipe jenis sesar mendatar kedua lempeng saling bergerak mendata [3].

\subsection{Tsunami}

Tsunami adalah bencana alam yang terjadi akiat adanya gempabumi dengan skala yang besar dibawah laut [4]. Tsunami merupakan salah satu jenis bencana alam yang berkaitan dengan gelombang laut besar yang menerjang daratan. Tsunami adalah gelombang laut besar yang dihasilkan oleh gempabumi di dasar samudera, letusan gunung api, atau longsoran masa batuan di sekitar samudera [5]. Karakteristik umum dari tsunami pada dasarnya berbeda dengan karakteristik ombak pada biasanya. Ombak merupakan gelombang air laut yang dihasilkan dari tiupan angin, sedangkan tsunami merupakan gelombang yang dibentuk akibat adanya kegiatan geologi bumi [6].

Tsunami tidak termasuk dalam gelombang tunggal tetapi berupa rangkaian gelombang pada laut dalam yang mana tinggi gelombangnnya hanya sampai $0,5 \mathrm{~m}$. Namun sewaktu mendekati pantai tingginya sampai $15 \mathrm{~m}$ bahkan lebih besar. Tsunami mempunyai gaya dorong yang sangat besar karena volume airnya sangat besar dan dipengaruhi oleh kecepatan aliran air. Kecepatannya mendekati pantai sekitar $48 \mathrm{~km} / \mathrm{jam}$ namun kekuatannya jutaan ton [7].

Untuk gempabumi bawah laut, mekanisme pembentukan gelombang tsunami adalah ketika gempa terjadi maka terdapat perpindahan yang nyata dari kerak samudera, yang secara tiba-tiba pengangkatan atau penurunan dasar laut. Jika hal tersebut terjadi, maka permukaan air laut di atas wilayah deformasi dasar laut akan menunjukkan deformasi (perubahan) yang serupa. Tsunami juga dapat terjadi disepanjang patahan horisontal, sehingga tsunami yang dihasilkan berupa tsunami lokal dan umumnya tidak menjalar menuju tempat yang jauh [8]. Kecepatan penjalaran gelombang tsunami bergantung pada kedalaman air. 
Jika kedalaman air berkurang maka kecepatan tsunami berkurang. Karena gelombang tsunami sangat panjang, bagian yang berbeda dari gelombang tersebut mungkin berada pada kedalaman yang lebih bervariasi secara luas (khususnya di daerah pantai) pada saat yang bersamaan, dimana kedalaman menentukan kecepatan gelombang, bagian yang berjalan dengan kecepatan yang berbeda, menyebabkan gelombang menekuk dan hal ini disebut pembiasan gelombang [9].

Klasifikasi tsunami berdasarkan penyebabnya dapat dibedakan menjadi dua jenis yaitu tsunami vulkanik dan tsunami tektonik. Jenis tsunami vulkanik adalah jenis tsunami yang disebabkan gempa yang berasal dari kegiatan vulkanik bumi, sedangkan tsunami tektonik disebabkan karena adanya gempa yang terjadi akibat aktivitas tektonik bumi. Adapun faktor-faktor yang dapat menyebabkan terjadinya tsunami yaitu a) Ada retakan di dasar laut yang disertai dengan adanya gempabumi. Retakan disini maksudnya adalah suatu lempeng bumi yang lemah kemudian melewati daerah kerak bumi. b) Ada tanah longsor, baik yang terjadi di bawah air atau yang berasal dari atas lautan yang kemudian menghujam ke dalam air. c) Ada aktivitas gunung berapi yang terletak di dekat pantai atau di bawah air yang sewaktu-waktu dapat terangkat atau tertekan seperti gerakan yang terjadi pada retakan.

\subsection{Tinggi tsunami}

Tinggi tsunami didefinisikan sebagai jarak vertikal antara puncak gelombang tsunami dengan titik nol muka laut (mean sea level) yang membesar pada saat tsunami menjalar dari pusat tsunami ke garis pantai. Tinggi tsunami akan mencapai nilai maksimum dipantai yang berbentuk seperti huruf $\mathrm{U}$ atau $\mathrm{V}$. Oleh karena itu, pantai yang berbentuk seperti pelabuhan, teluk atau muara sungai tergolong sebagai pantai yang raw an terhadap bencana tsunami [10]. Untuk perbedaan tinggi tsunami dengan run-up dapat di lihat pada Gambar 1.

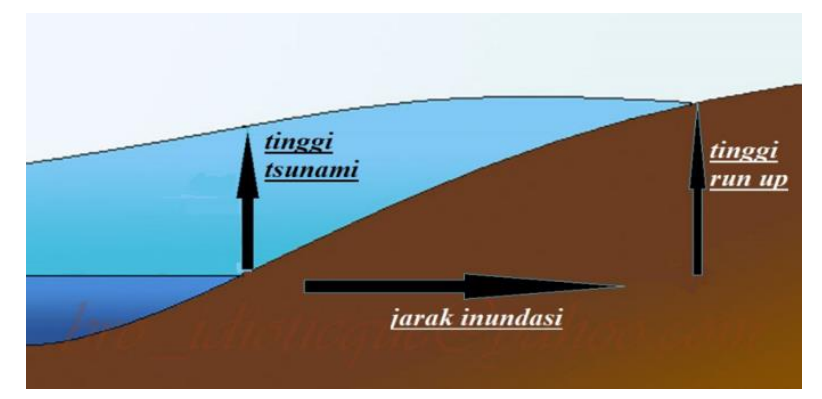

Gambar 1. Perbedaan tinggi tsunami dengan run-up [10].

\subsection{Run-up tsunami}

Run-up tsunami merupakan tinggi gelombang air laut yang dihitung dari batas akhir inundasi gelombang tsunami dari titik nol muka laut atau mean sea level. Tinggi run-up dan tinggi tsunami bergantung pada magnitudo gempabumi, morfologi dasar laut, dan bentuk pantai. Batas atas run-up merupakan parameter yang sangat penting untuk menentukan profil pantai. Kesulitan yang kerap ditemui saat memprediksi run-up adalah transformasi gelombang air laut serta refleksi gelombang. Kecepatan run-up kedaratan bisa mencapai $25-100 \mathrm{~km} / \mathrm{jam}$. Kembalinya air ke laut setelah mencapai puncak gelombang (run down) juga bersifat merusak karena menyeret segala sesuatu kembali ke laut [10].

\subsection{Tsunami Observation and Simulation Terminal (TOAST)}

Tsunami Observation and Simulation Terminal adalah sebuah perangkat lunak untuk simulasi dan verifikasi tsunami dimana potensi bahaya dan penilaian terhadap tsunami yang terjadi diberikan dengan cepat. TOAST dikembangkan oleh gesellschaft mit beschrankter hafting $(\mathrm{GmbH})$. TOAST memiliki sebuah aplikasi yang dinamakan easywave. Easywave menggunakan data pengukuran kedalaman sebagai model input untuk wilayah lautan agar bisa disimulasikan. Data yang dihasilkan merupakan data dua dimensi. Komputasi yang dibawa oleh data dua dimensi ini kemudian mengalami pengulangan dalam sebuah loop12 waktu dan terbagi menjadi dua bagian yaitu ketinggian gelombang dan fluks yang terbalik [11].

TOAST sangat fleksibel karena menggunakan pendekatan real time atau online simulasi. Pada saat kejadian tsunami berlangsung, TOAST dapat dengan cepat memproses pemodelan tsunami secara real time dan langsung memberikan hasil. Terdapat tiga status peringatan pada TOAST yaitu a) SIAGA, 
yang diharap memperhatikan dan segera mengarahkan masyarakat untuk melakukan evakuasi. b) WASPADA, yang diharap memperhatikan dan segera mengarahkan masyarakat untuk menjauhi pantai dan tepian sungai. c) AWAS, yang diharap memperhatikan dan segera mengarahkan masyarakat untuk melakukan evakuasi menyeluruh.

\section{Metode Penelitian}

Penelitian ini dilakukan di Balai Besar Meteorologi, Klimatologi, dan Geofisika Wilayah III Denpasar. Proses pengolahan data menggunakan software TOAST. Data yang digunakan dalam penelitian adalah data sekunder yaitu data kedalaman gempabumi 18, 35, dan $65 \mathrm{~km}$. Data magnitude gempabumi penyebab tsunami 7, 7,5,8 dan 8,5 yang diambil dari buku pusat gempa BMKG. Berikut adalah alur penelitian dari sejumlah keseluruhan kegiatan yang dilakukan dapat di lihat pada Gambar 2.

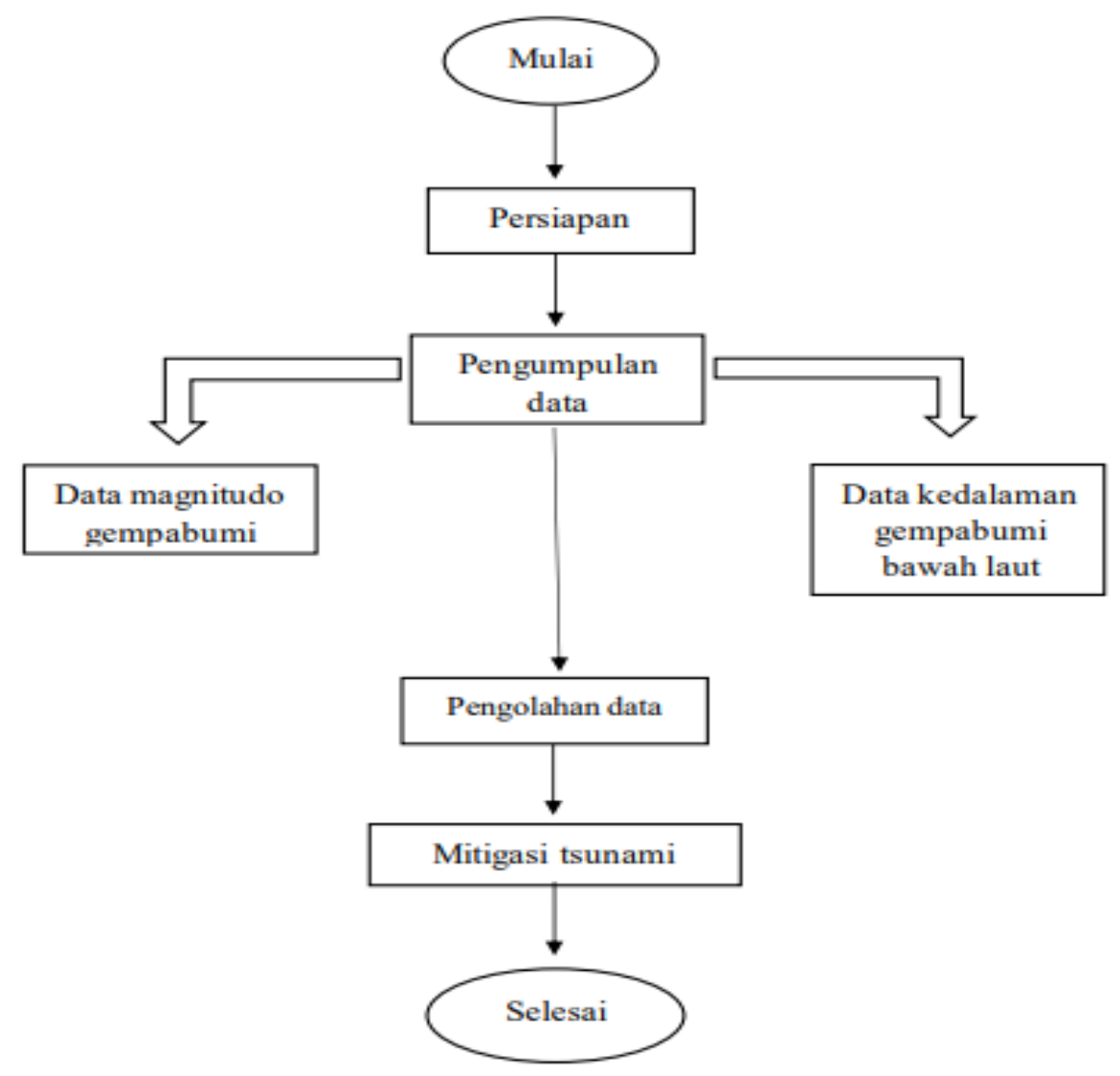

Gambar 2. Alur penelitian.

Tahap pertama pengolahan data yaitu persiapan. Tahap persiapan ini seperti mempersiapakan alat dan aplikasi apa yang akan dipakai dalam penelitian ini, hal ini juga berguna untuk meminimalisir sesuatu yang tidak diinginkan selama pengolahan data berlangsung. Pengumpulan data yang dilakukan yaitu data magnitudo gempabumi penyebab tsunami dan data kedalaman gempabumi bawah laut. Setelah dilakukan pengumpulan data, Kemudian data di input ke software TOAST dengan memasukkan data kedalaman gempabumi dan juga memasukkan data magnitudo minimum sampai maksimum, kemudian memasukkan letak episenter wilayah yang akan diteliti. Maka didapat tinggi run-up dan waktu tiba pada tiap-tiap magnitude sehingga bisa dirancang mitigasi tsunami di daerah Banyuwangi.

\section{Hasil Dan Pembahasan}

4.1 Hasil (run-up dan waktu tiba tsunami)

Adapun hasil-hasil perhitungan run-up dan waktu tiba tsunami dengan memanfaatkan data sekunder yang diperoleh dari buku pusgen ditampilkan pada Table 1 dan 2. Dengan magnitudo gempabumi, place yaitu daerah, province yaitu provinsi, country yaitu negara, depth yaitu kedalaman gempabumi, Run-up, T1 yaitu tinggi awal tsunami saat terjadinya tsunami, T1 time yaitu waktu tiba tsunami. 
Tsunami Disaster Mitigation Studyby Determining Run-up and The Banyuwangi ........ (IPutu Agum Suriajaya Maha Putra, dkk)

Tabel 1. Tabel hasil data run-up dan waktu tiba tsunami Banyuwangi bagian selatan.

\begin{tabular}{|c|c|c|c|c|c|c|c|}
\hline Mangnitudo & Place & Province & Country & $\begin{array}{l}\text { Depth } \\
(\mathrm{km})\end{array}$ & $\begin{array}{l}\text { Run-up } \\
\text { (m) }\end{array}$ & $\begin{array}{c}\mathrm{T} 1 \\
\text { value }\end{array}$ & $\begin{array}{c}\mathrm{T} 1 \\
\text { (menit) }\end{array}$ \\
\hline 7,0 & $\begin{array}{l}\text { Banyuwangi } \\
\text { bagian selatan }\end{array}$ & $\begin{array}{l}\text { Jawa } \\
\text { Timur }\end{array}$ & Indonesia & 18 & 0,301 & 0,010 & 00.27 .00 \\
\hline 7,5 & $\begin{array}{l}\text { Banyuwangi } \\
\text { bagian selatan }\end{array}$ & $\begin{array}{l}\text { Jawa } \\
\text { Timur }\end{array}$ & Indonesia & 18 & 1,731 & 0,010 & 00.27 .00 \\
\hline 8,0 & $\begin{array}{l}\text { Banyuwangi } \\
\text { bagian selatan }\end{array}$ & $\begin{array}{l}\text { Jawa } \\
\text { Timur }\end{array}$ & Indonesia & 18 & 3,277 & 0,010 & 00.12 .40 \\
\hline 8,5 & $\begin{array}{l}\text { Banyuwangi } \\
\text { bagian selatan }\end{array}$ & $\begin{array}{l}\text { Jawa } \\
\text { Timur }\end{array}$ & Indonesia & 18 & 9,718 & 0,010 & 00.08 .19 \\
\hline 7,0 & $\begin{array}{l}\text { Banyuwangi } \\
\text { bagian selatan }\end{array}$ & $\begin{array}{l}\text { Jawa } \\
\text { Timur }\end{array}$ & Indonesia & 35 & 0,264 & 0,010 & 00.14 .19 \\
\hline 7,5 & $\begin{array}{l}\text { Banyuwangi } \\
\text { bagian selatan }\end{array}$ & $\begin{array}{l}\text { Jawa } \\
\text { Timur }\end{array}$ & Indonesia & 35 & 1,048 & 0,010 & 00.12 .00 \\
\hline 8,0 & $\begin{array}{l}\text { Banyuwangi } \\
\text { bagian selatan }\end{array}$ & $\begin{array}{l}\text { Jawa } \\
\text { Timur }\end{array}$ & Indonesia & 35 & 3,366 & 0,010 & 00.08 .48 \\
\hline 8,5 & $\begin{array}{l}\text { Banyuwangi } \\
\text { bagian selatan }\end{array}$ & $\begin{array}{l}\text { Jawa } \\
\text { Timur }\end{array}$ & Indonesia & 35 & 9,905 & 0,010 & 00.03.19 \\
\hline 7,0 & $\begin{array}{l}\text { Banyuwangi } \\
\text { bagian selatan }\end{array}$ & $\begin{array}{l}\text { Jawa } \\
\text { Timur }\end{array}$ & Indonesia & 65 & 0,117 & 0,010 & 00.07 .19 \\
\hline 7,5 & $\begin{array}{l}\text { Banyuwangi } \\
\text { bagian selatan }\end{array}$ & $\begin{array}{l}\text { Jawa } \\
\text { Timur }\end{array}$ & Indonesia & 65 & 0,565 & 0,010 & 00.06 .40 \\
\hline 8,0 & $\begin{array}{l}\text { Banyuwangi } \\
\text { bagian selatan }\end{array}$ & $\begin{array}{l}\text { Jawa } \\
\text { Timur }\end{array}$ & Indonesia & 65 & 2,102 & 0,010 & 00.04 .00 \\
\hline 8,5 & $\begin{array}{l}\text { Banyuwangi } \\
\text { bagian selatan }\end{array}$ & $\begin{array}{l}\text { Jawa } \\
\text { Timur }\end{array}$ & Indonesia & 65 & 6,246 & 0,010 & 00.04 .00 \\
\hline
\end{tabular}

Tabel 2. Tabel hasil data run-up dan waktu tiba tsunami Banyuwangi bagia timur.

\begin{tabular}{|c|c|c|c|c|c|c|c|}
\hline Mangnitudo & Place & Province & Country & $\begin{array}{c}\text { Depth } \\
(\mathrm{km})\end{array}$ & $\begin{array}{c}\text { Run-up } \\
\text { (m) }\end{array}$ & $\begin{array}{c}\mathrm{T} 1 \\
\text { value }\end{array}$ & T1 time \\
\hline 7,0 & $\begin{array}{l}\text { Banyuwangi } \\
\text { bagian timur }\end{array}$ & $\begin{array}{c}\text { Jawa } \\
\text { Timur }\end{array}$ & Indonesia & 18 & 0,051 & 0,010 & 00.35 .00 \\
\hline 7,5 & $\begin{array}{l}\text { Banyuwangi } \\
\text { bagian timur }\end{array}$ & $\begin{array}{l}\text { Jawa } \\
\text { Timur }\end{array}$ & Indonesia & 18 & 0,256 & 0,010 & 00.34 .00 \\
\hline 8,0 & $\begin{array}{l}\text { Banyuwangi } \\
\text { bagian timur }\end{array}$ & $\begin{array}{l}\text { Jawa } \\
\text { Timur }\end{array}$ & Indonesia & 18 & 0,607 & 0,010 & 00.17 .10 \\
\hline 8,5 & $\begin{array}{l}\text { Banyuwangi } \\
\text { bagian timur }\end{array}$ & $\begin{array}{l}\text { Jawa } \\
\text { Timur }\end{array}$ & Indonesia & 18 & 2,573 & 0,010 & 00.12 .04 \\
\hline 7,0 & $\begin{array}{l}\text { Banyuwangi } \\
\text { bagian timur }\end{array}$ & $\begin{array}{l}\text { Jawa } \\
\text { Timur }\end{array}$ & Indonesia & 35 & 0,033 & 0,010 & 00.20 .55 \\
\hline 7,5 & $\begin{array}{l}\text { Banyuwangi } \\
\text { bagian timur }\end{array}$ & $\begin{array}{l}\text { Jawa } \\
\text { Timur }\end{array}$ & Indonesia & 35 & 0,174 & 0,010 & 00.17 .40 \\
\hline 8,0 & $\begin{array}{l}\text { Banyuwangi } \\
\text { bagian timur }\end{array}$ & $\begin{array}{l}\text { Jawa } \\
\text { Timur }\end{array}$ & Indonesia & 35 & 0,768 & 0,010 & 00.13 .04 \\
\hline 8,5 & $\begin{array}{l}\text { Banyuwangi } \\
\text { bagian timur }\end{array}$ & $\begin{array}{l}\text { Jawa } \\
\text { Timur }\end{array}$ & Indonesia & 35 & 3,399 & 0,010 & 00.17 .19 \\
\hline 7,0 & $\begin{array}{l}\text { Banyuwangi } \\
\text { bagian timur }\end{array}$ & $\begin{array}{l}\text { Jawa } \\
\text { Timur }\end{array}$ & Indonesia & 65 & 0,030 & 0,010 & 00.16 .10 \\
\hline 7,5 & $\begin{array}{l}\text { Banyuwangi } \\
\text { bagian timur }\end{array}$ & $\begin{array}{l}\text { Jawa } \\
\text { Timur }\end{array}$ & Indonesia & 65 & 0,165 & 0,010 & 00.10 .40 \\
\hline 8,0 & $\begin{array}{l}\text { Banyuwangi } \\
\text { bagian timur }\end{array}$ & $\begin{array}{l}\text { Jawa } \\
\text { Timur }\end{array}$ & Indonesia & 65 & 0,858 & 0,010 & 00.04 .55 \\
\hline 8,5 & $\begin{array}{l}\text { Banyuwangi } \\
\text { bagian timur }\end{array}$ & $\begin{array}{l}\text { Jawa } \\
\text { Timur }\end{array}$ & Indonesia & 65 & 3,234 & 0,010 & 00.04 .00 \\
\hline
\end{tabular}

Dari hasil yang didapat pada Tabel 1 dan 2, daerah dengan run-up tertinggi yaitu Banyuw angi bagian selatan dengan tinggi run-up 9,718 m pada kedalaman gempabumi $18 \mathrm{~km}$ dibawah laut dan magnitudo 
gempa 8,5 sedangkan waktu tiba tsunami paling cepat mencapai daratan yaitu 4 menit setelah terjadinya tsunami.

\subsection{Pembahasan}

Telah dilakukan studi mitigasi bencana tsunami di Kabupaten Banyuwangi dengan menentukan tinggi run-up dan waktu tiba tsunami. Pengambilan data dilakukan di Badan Meteorologi, Klimatologi dan Geofisika wilayah 3 Denpasar dengan menggunakan software TOAST, adapun data yang digunakan dalam penelitian ini yaitu memanfaatkan data sekunder berupa data dengan magnitudo minimim 7,0 sampai dengan magnitudo maksimum 8,5 yang berpotensi menyebabkan tsunami dan data yang digunakan selanjutnya yaitu data kedalaman gempabumi bawah laut dengam kedalaman paling dangkal yaitu $18 \mathrm{~km}$ sampai kedalaman maksimum yaitu $65 \mathrm{~km}$ yang bisa menyebabkan tsunami di Banyuwangi.

Berdasarkan data run-up pada Tabel 1 dan 2, diperoleh nilai sebesar sebesar 9,718 m yang kemudian digunakan sebagai acuan untuk menentukan ketinggian tempat evakuasi, seperti dalam menentukan tinggi gedung minimum ataupun menuju dataran yang lebih tinggi. Sedangkan data waktu tiba tsunami sampai ke pesisir pantai yaitu 4 menit, digunakan sebagai estimasi waktu evakuasi ke gedung-gedung ataupun dataran yang lebih tinggi dari hasil perhitungan run-up. Dalam rentang waktu perkiraan tersebut, tidak semua dapat digunakan sebagai waktu evakuasi, namun terdapat waktu persiapan dan waktu untuk naik kegedung lantai dua. Berdasarkan hasil penelitian [7] maka didapatkan hasil kecepatan lari rata-rata penduduk, dapat dilihat pada Tabel 3. Analisis waktu tersebut juga dilakukan dengan menghitung kecepatan lari masyarakat.

Tabel 3. Data usia penduduk dan kecepatan berlari.

\begin{tabular}{cll}
\hline No & \multicolumn{1}{c}{ Usia penduduk } & \multicolumn{1}{c}{ Kecepatan berlari } \\
\hline 1 & 5-15 tahun & $5,88 \mathrm{~m} / \mathrm{s}$ \\
2 & Laki-laki usia 15-30 tahun & $18,75 \mathrm{~m} / \mathrm{s}$ \\
3 & Perempuan usia 15-30 tahun & $6,67 \mathrm{~m} / \mathrm{s}$ \\
4 & Perempuan diatas 30tahun & $5 \mathrm{~m} / \mathrm{s}$ \\
5 & Laki-laki di atas 30 tahun & $12 \mathrm{~m} / \mathrm{s}$ \\
\hline
\end{tabular}

Skenario mitigasi berdasarkan data daerah dataran tinggi dan data bangunan yang digunakan dalam mitigasi bencana tsunami dapat dilakukan evakuasi, dengan skenario-skenario yang harus dilakukan saat terjadi tsunami sebagai berikut.

a. Kecamatan Banyuw angi

Total gedung yang ada di daerah Banyuwangi yaitu 7.373 gedung, dengan kepadatan penduduk 105.925 orang. Berdasarkan data tersebut dapat dihitung dan diperkirakan setiap 1 gedung menampung 15 orang.

b. Kecamatan Kabat

Total gedung yang ada di daerah Kabat yaitu 2.297 gedung, dengan kepadatan penduduk 30.502 orang. Berdasarkan data tersebut dapat dihitung dan diperkirakan setiap 1 gedung menampung 14 orang.

c. Kecamatan Rogojampi

Total gedung yang ada di daerah Rogojampi yaitu 2.615 gedung, dengan kepadatan penduduk 31.171 orang. Berdasarkan data tersebut dapat dihitung dan diperkirakan setiap 1 gedung menampung 12 orang.

d. Kecamatan Muncar

Total gedung yang ada di daerah Muncar yaitu 8.569 gedung, dengan kepadatan penduduk 75.495 orang. Berdasarkan data tersebut dapat dihitung dan diperkirakan setiap 1 gedung menampung 9 orang.

e. Kecamatan Tegaldlimo

Total gedung yang ada di daerah Tegaldlimo yaitu 2.338 gedung, dengan kepadatan penduduk 53.788 orang. Berdasarkan data tersebut dapat dihitung dan diperkirakan setiap 1 gedung menampung 24 orang.

f. Kecamatan Purwoharjo

Total gedung yang ada di daerah Purwoharjo yaitu 917 gedung, dengan kepadatan penduduk 20.734 orang. Berdasarkan data tersebut dapat dihitung dan diperkirakan setiap 1 gedung menampung 23 orang. 
g. Kecamatan Bangorejo

Total gedung yang ada di daerah Bangorejo yaitu 3.368 gedung, dengan kepadatan penduduk 30.831 orang. Berdasarkan data tersebut dapat dihitung dan diperkirakan setiap 1 gedung menampung 10 orang.

h. Kecamatan Pesangaran

Total ge dung yang ada di daerah Siliragung yaitu 3.782 gedung, dengan kepadatan penduduk 40.740 orang. Berdasarkan data tersebut dapat dihitung dan diperkirakan setiap 1 gedung menampung 11 orang.

\section{Kesimpulan}

Berdasarkan hasil dan pembahasan, dapat disimpulkan bahwa run-up maksimum yaitu 9,718 m dan estimasi waktu tercepat datangnya tsunami yaitu 4 menit. Sehingga, dapat dibuat model mitigasi bencana tsunami. Adapun daerah Banyuwangi yang terdampak tsunami dan perlu diwaspadai yaitu Banyuwangi bagian selatan dan Banyuw angi bagian timur. Maka dapat diperkirakan sekitar 389.186 orang penduduk yang di evakuasi ke daerah yang aman dari bencana tsunami dengan jumlah gedung yang akan dipakai sebagai tempat evakuasi di daerah yang raw an terdampak tsunami yaitu 31.259 gedung.

\section{Ucapan Terima Kasih}

Penulis menyampaikan terimakasih kepada BMKG Wilayah III Denpasar yang telah memberikan bantuan fasilitas dalam penelitian ini. Serta staf dosen bidang minat Fisika Bumi, Prodi Fisika, FMIPA, UNUD yang telah memberikan saran serta masukan terkait penelitian ini.

\section{Pustaka}

[1] B. Baskara, Pemetaan Bahaya Gempa Bumi Dan Potensi Tsu-Nami Di Bali Berdasarkan Nilai Seismisitas, Buletin Fisika, Vol. 18, No. 1, 2017, pp: 20-26.

[2] P. Supendi, Analisis Aktifitas Seismik di Jawa Barat dan sekitarnya, Skripsi, Jurusan Geofisika, Akademi Meteorologi dan Geofisika, Jakarta.

[3] A. Hijriani, Peningkatan Akurasi Lokasi Gempa Mikro Dengan Menggunakan Metoda DoubleDifference Dan Korelasi Silang Master Waveform, Jurnal Geofisika, Vol. 15, No. 3, 2017, pp: 2125.

[4] H. M. F. Haykal, Nasrurroh A, Estimasi Durasi Pecah dan Nilai Mwp untuk Mengidentifikasi Gempa Bumi Pembangkit Tsunami di Sulawesi Utara, Jurnal Geofisik, Vol. 17, No. 1, 2019, pp: $10-15$.

[5] Priadi, Ramadhan Et Al. Analisis Karakteristik Tsunami Donggala-Palu Berdasarkan Durasi Ruptur (Tdur) dan Orientasi Sesar Aktif Menggunakan Metode HC-plot. Jurnal Geofisika, [S.1.], v. 17, No.1, 2019, pp:16-20.

[6] U. A. Riadi, N. Andri D, and S. Hasbi Ash, Hypocenter relocations and tsunami simulation for the 15 November 2014 Northern Moluc ca Sea earthquake in Indonesia, Jurnal Geofisika, Vol. 15, No. 3, 2017, pp: 1-9.

[7] BMKG, peta sumber dan bahaya gempa Indonesia tahun 2017, Buku Katalog histori gempa bumi BMKG, 2017.

[8] Pertiwi, Imanuela I, Fattah, and M. H. Rauf, Estimation Of Tsunami Inundation And Disaster Mitigation In Bulukumba Indonesia, Jurnal Geofisika, Vol 16. No.1, 2018, pp: 1-8.

[9] A.Saptaji, Pengukuran Tsunami, Laporan Penelitian, 2012.

[10] Nurhidayani, Mitigation Scheme for Banggae Future Tsunami, Jurnal, Universitas Hasanuddin, 2015. 